\title{
The Effect of Tourism Expenditure on the Economy: A New Evidence
}

\author{
(Kesan Perbelanjaan Pelancongan terhadap Ekonomi: Suatu Bukti Baharu)
}

\author{
Norma Azuli Mohd Nor \\ Universiti Kebangsaan Malaysia \\ Norlida Hanim Mohd Salleh \\ Universiti Kebangsaan Malaysia
}

\author{
A Faroby Falatehan \\ IPB University
}

\begin{abstract}
The aim of this study is to evaluate the impact of development on the Malaysian economy through the impact of tourist expenditure by using the Social Accounting Matrix (SAM). The discussion of the study focused on the value of multipliers, factors of production and household income from tourism activities in urban and rural areas. The results had shown that tourist expenditure on the arts, entertainment and recreation subsectors produced the largest multiplier effect on output. Meanwhile, other sub-sectors such as shopping, food and beverage, accommodation and transportation did not show significant differences. In addition, there is a large income distribution gap in urban and rural areas although income distribution to factors of production and households has a positive effect. This inequality needs to be addressed to ensure that tourism development can benefit the overall economy. Among the steps that can be done is Community-Based Tourism (CBT) which involves collaboration between local communities and stakeholders to support authenticity, environmental sustainability, and strengthen management and supervision. It is expected to overcome the problems encountered as a result of the findings of the study. This is expected to increase the positive economic impact of tourism development.
\end{abstract}

Keywords: Income distribution; output multiplier; social accounting matrix; tourism JEL: B21, C63, C67, Z32

ABSTRAK

Kajian ini bertujuan menilai impak pembangunan kepada keseluruhan ekonomi Malaysia melaui kesan perbelanjaan pelancongan menggunakan Matriks Perakaunan Sosial (SAM). Perbincangan kajian memfokuskan kepada nilai pengganda, faktor pengeluaran dan pendapatan isi rumah daripada aktiviti pelancongan di kawasan bandar dan luar bandar. Hasil kajian menunjukkan perbelanjaan pelancongan ke atas sub sektor seni, hiburan dan rekreasi menghasilkan kesan penganda yang terbesar ke atas output. Manakala, sub-sektor lain seperti membeli belah, makanan dan minuman, penginapan dan pengangkutan tidak menunjukkan perbezaan yang ketara. Selain itu, wujud jurang pengagihan pendapatan yang besar di kawasan bandar dan luar bandar walaupun agihan pendapatan kepada faktor pengeluaran dan isi rumah mempunyai kesan positif. Ketidaksamaan ini perlu diatasi bagi memastikan pembangunan pelancongan dapat memberi manfaat kepada keseluruhan ekonomi. Antara langkah yang boleh dilakukan adalah melalui Pelancongan Berasaskan Komuniti (CBT) yang melibatkan kerjasama antara komuniti tempatan dan pemegang taruh bagi menyokong keaslian, persekitaran kelestarian, dan memperkukuhkan pengurusan dan penyeliaan. Langkah ini diharapkan dapat meningkatkan kesan ekonomi pembangunan pelancongan yang positif.

Kata kunci: Agihan pendapatan; pengganda output; matrik perakaunan sosial; pelancongan.

Received 11 August 2018; Revised 31 August 2021; Accepted 31 August 2021; Available online 31 August 2021

\section{INTRODUCTION}

The tourism industry is globally recognized as the most important sector in generating country income as well as economic growth through engendering the gross domestic product (revenue) (Theobald 2005). According to the United Nation World Tourism Organization (UNWTO 2017) international tourist arrivals rose from 25 million in 1950 to 278 million in 1980, 674 million in 2000 and 1, 235 million in 2016. In terms of tourism receipts, about USD2 billion were generated in 1950 from the tourism industry, rising to USD104 billion in

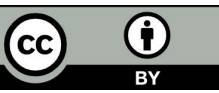

This article is published under the Creative Commons Attribution 4.0 International (CC BY 4.0) license. 
1980, USD495 billion in 2000 and USD1, 220 billion in 2016. These figures show that in terms of annual growth rate, tourist arrivals grew at $6.1 \%$ per annum during the 1950-2016 period and tourism receipts grew by $10.2 \%$ per annum in more than 6 decades. Growth in tourism provides a strong stimulus to the growth of the world economy.

The development and growth of the world's tourism economy also influence the growth of the tourism sector in Malaysia as well as those in other countries. In 2014, Malaysia was ranked 12th in terms of the world's largest tourist arrivals and 13th in terms of total revenue earned from foreign tourists (UNWTO 2016). The tourism sector has become the sixth most important sector as a contributor to Malaysia's economic growth in 2014 (Hafiz 2017). Malaysia was visited by 26.757 million tourists in 2016 and earned a total of RM82.092 billion in revenue. The tourism sector contributed $7.4 \%$ to Gross Domestic Product (GDP) and $10.4 \%$ to exports in the same year. The contributions of tourism income to GDP and exports between 2000 and 2017 showed increasing trends. The tourism income ratio with GDP rose from 3.3\% (year 2000 ) to $7.4 \%$ (2016) and the ratio with exports rose from $4.6 \%$ to $10.4 \%$ for the respective years. The economic contribution by the tourism industry sector and the impact it directly exerted on the economy (on the GDP and export). In reality, the impact on the economy through this particular sector is actually broader due to the very strong relationships that exist between the various sectors in the economy. In other words, there exist an indirect impact and the induced impact of the tourism industry on the economy as a whole.

The analysis of this impact of tourism spending on economic sub-sectors and the linkages between the various sectors or industries can be accomplished by using the Input-Output (IO) method. According to Rashidah (2012), tourism in Malaysia contributes significantly to the economy in term of generating output and household income, meanwhile base on inter sectoral linkages analysis, it showed tourism is a key sector in creating demand and stimulating production within the sector as well as other sector of the economy.

This advantage of analyzing linkages placed the IO method above other approaches such as econometrics that are limited to the analysis of single industries. However, the IO also has the disadvantage of not being able to clearly demonstrate the distribution in a complete economic system. A more detailed distribution can be analysed using the method of Social Accounting Matrix (SAM). Until this paper was written, the SAM Table from the Department of Statistics Malaysia was not available for public use. As such this study will endeavor to develop the SAM specifically for studying the tourism sector in Malaysia. This paper aims to elucidate the income multiplier based on the SAM approach and accordingly examine the impact of tourist expenditure on Malaysia's economy.
To achieve this, a SAM Malaysia Table 2005 was developed through the modification of data from the IO Table 2005 and tourism data of the same year. The study will evaluate the intersectoral impact (identifying the sub-sector in the industry that receives the biggest impact and the overall effect on the whole sectors of the Malaysian economy) as well as income distribution to labor and households as a result of demand shock through income multipliers from direct, indirect and induced effects. Although SAM 2005 was used, the approach is still relevant in terms of impact estimation since Malaysia's economic structure has not changed much since that date (Bank Negara Malaysia 2012).

This study contributes to the policy makers and existing literature in following ways. First, is important as it assesses the real impact of the tourism sector on the economy as a whole. In addition to explaining the real recipients of the economic growth of tourism. It can also be used as a more efficient basis for stakeholders in planning future development. In terms of knowledge generation, this study can form the basis for the development of SAM method in future research. This is because this study describes in detail the steps in developing SAM based on the stone method (1986). Therefore, this study was conducted to analyze impact of tourism development in Malaysia to the factors of production and the income household in urban and rural areas.

Following this introduction, the paper is subsequently organized with a section on literature review, followed by an explanation on methodology, discussion on empirical analysis of research findings, conclusion and finally, ending with research implications.

\section{LITERATURE REVIEW}

Researchers studying the impact of tourism industry on economic growth have employed various approaches. However, the literature largely reported on econometric studies that use multivariate regressions and causality techniques to examine the relationship between tourist expenditures and Gross Domestic Product (GDP) or employment (Akkemik 2012). Tosun et al. (2003) claimed that measuring full economic and developmental impacts of tourism was difficult due to various components of the tourism industry on both supply and demand sides. They argued that, there was no reliable method to assess the economic contribution of tourism to economic growth. Base on Akkemik (2012), Social Accounting Matrix (SAM) analysis represents the flows of the economic transactions existing in an economy, regional or national. Therefore, to solve the problem, Akkemik (2012) suggested the IO, SAM and Computable General Equilibrium (CGE) modeling techniques to analyse intersectoral relations in an economy. 
The IO method was given more attention by researchers as it is easier to implement in terms of data availability. Among the studies that used this approach, specifically in tourism, included Archer (1995); Archer and Fletcher (1996); Fletcher (1989); Frechtling and Horvath (1999); Henry and Deany (1997); Kweka et al. (2003) Mazumder et al. (2009); Salleh et al. (2012); Summary (1987); Surendra (2000), Zakariah and Bashir (2004) and Aliah (2016).

Aliah (2016) conduct research about role of tourism sector in economic development of Indonesia. This research used SAM approach. According to this researched, tourism sector has important role to economy of Indonesian. Foreign tourist consumption has greater impact to national income consumption of domestic tourist. Tourism development has directly impact to the development of the agricultural workforce, agricultural households and the hotel sector.

In Malaysia context, the IO method is more likely to be used in the assessment of the tourism industry's impact on the economy as compare to the others industry. For example, the study by Mazumder et al. (2009) shows that international tourist expenditures have a significant impact on the Malaysian economy through its contribution to output, income, employment, and valueadded. Meanwhile, Othman et al. (2011) have analyzed the travel patterns of several major Malaysian tourist markets and examined the impact of their per capita expenditures on the Malaysian economy. They found that tourists from West Asia market provide the highest contribution to the Malaysian economy compared to tourists from other markets. Norma et al. (2014) analyzed the impact of domestic tourist expenditures on the Malaysian economy. The study found that domestic tourists' expenditures were not as higher as compared to expenditure made by foreign tourists, however, their impact was still significant to the Malaysian economy by preventing the outflow of local currency.

However, the IO could only determine the intersectoral impact on the economy, but not the distribution of wages and income of labor and household. Therefore, another tool should be used to analyzing the impact of tourism to economy. Hughes and Shields (2007), Wagner (1997), Mansury and Hara (2007), Made (1999), De Agostini et al. (2005), Daniels et al. (2004) and Taylor et al. (2006) have resorted to apply SAM analysis to examine the numerous effects, including income distribution that the tourism industry has on the economy of various countries.

Using SAM, there are mixed finding between the researchers. Mansury and Hara (2007), reported that the growth of the tourism industry could increase output of production and generate a more equality in income distribution. This studies supported by Croes and Rivera (2017) and Eric (2013). Studied by Alam and Paramati (2015), Kinyondo and Palizzo (2015), and $\mathrm{Li}$ et al. (2016) also shown tourism development significant influence in reducing income inequality. However, some studies in developing countries, for example, Van de Walle and Gunewardena (2009) in Vietnam and Agostini et al. (2010) in Chile, reported that ethnic minorities earn lower incomes from tourism activity. Therefore, tourism development resulted on the inequality of income distribution. In Malaysia, the scenario is different since the ethnic majority generally earns lower incomes distribution. This may due mainly to the "Divide and Rule Policy" imposed by the British Era Colonial Administration. The policy was instrumental in separating economic functions between ethnic groups (Saari et al. 2015). According to the policy, the majority Malay and indigenous ethnic groups which were mainly rural dwellers were to focus on agricultural activities, while ethnic minorities like the migrant Chinese and Indians who mostly populated the urban areas were to partake in business activities and other professional occupations. This policy eventually became the root cause for income inequality among the main ethnic groups in Malaysia today (Dziauddin et al. 2016).

Given this background, this study examined the effect of tourist expenditure on the wages and income distribution of urban and rural labor and households in Malaysia. Previous studies such as those by Saari et al. (2015), Harun et al. (2012a) and Saari et al. (2016) also examined the disparities in income distribution by ethnic groups and in the rural-urban divide, through using the SAM method, however, these studies did not address the tourism sector per se.

\section{RESEARCH METHODOLOGY}

There are two approaches in the development of SAM, i.e. top-down approach and bottom-up approach (Sue Wing 2006; Bohringer et al. 2007). Consistent with the method employed by Pyatt and Round (1984) and Saari et al. (2014), this study will adopt the top-down approach. The same methodology is used to develop SAM instead of the limitation in gathering data. The approach is also cost effective and time-saving. To balance each row and column in the SAM account, the General Algebraic Modeling System (GAMS) is used.

As compared with other econometric models, the IO, SAM and CGE in common have more advantages since all three models account for the input-output relationship in the inter-industry account, as well as in final demand (utilization, investment, export and import). Akkemik (2012) ventured that these approaches are more superior to other econometric methods with regard to quantitative studies that gauged the contribution of tourism demand on the entire economy.

Nevertheless, the IO model disregards the main economic aspect by mainly focusing on industries that are directly affected and have direct relationship with 
other sectors of the economy. As a result, the impact estimation of IO on economic activities tend to be generally greater and with higher margin (Dwyer et al. 2004). Traditionally, the utilization of SAM is concentrated on quantitative modelling and income effect. In addition, it has several benefits over IO. SAM provides a simple framework in the merging and displaying of data and illustrates economic structure in terms of the relationship among production, income distribution and demand in the economy (Thorbecke, 1988). Since one of the study's objectives is to examine the effect of income distribution on production and households, the SAM approach is considered more appropriate over the IO.

The SAM approach is an analytical and predictive tool to represent and forecast system-wise effects of changes in exogenous factors. There's an advantage of this approach is its ability to capture a wide variety of developments in a (macro-) economy, as it links production, factor and income accounts. A large share of economic interactions takes place within the household sector and a SAM disaggregates the cells involving 'returns for labour' and the household sector into smaller groups to show the effect of the different behaviour of these groups. Furthermore, according to Alarcon et al (1991) in Leeuwen and Nijkamp (2009), Social Accounting Matrices approach is a relatively efficient way of presenting data, the presentation of data in a SAM immediately shows the origin and destination of the various flows included. Another advantage of SAM approach is usefulness as a tool to reconcile different data sources and fill in the gaps. This enables the reliability of existing data to be improved and inconsistencies in data sets of different nature and origin to be revealed.

\section{MODELLING SOCIAL ACCOUNTING MATRIX} (SAM)

In modelling SAM, some assumptions were used. First, all economic activities at national or regional level (as classified by the Malaysia Standard Industrial Classification (MSIC) 2000) are included in the sectors and institutions. Second, there is general stability where total expenditure and income of each sector or institution are balanced and third, the coefficient distribution between sectors or institution is constant. However, these assumptions have resulted in limitation to the SAM model since there is no constraints in supply. This means that the need for goods and services for utilization and investment will always be fulfilled, the relative price between input and output prices is constant, and the relationship between sectors or institutions is constant. SAM is, therefore, a static model, whereby its coefficient or parameter is constant and there is no overlapping of roles between sectors and institutions.

The development of SAM requires data from various sources. To build SAM for Malaysia in 2005, the main source of data was from the publications of the Department of Statistics, Malaysia such as the Malaysia Input-Output Table 2005, Distribution Account and Use of Income and Capital Account 2005, National Accounts Publication 2005, Capital Account and Population and Housing Census Statistics 2009 and Malaysia Labor Force Survey Report 2011. Other sources of data include those from Bank Negara Annual Report and The Migration and Remittances Factbook 2011 by the World Bank.

Since SAM Malaysia Table by the Department of Statistics Malaysia was then not readily available to the public, SAM Malaysia Table 2005 was developed in order to achieve this study's objective. This latter table was built in the form of $134 \times 134$ matrix. The disaggregate level of each individual account in its construction depends on the subject that is to be examined. The said matrix has accordingly undergone disaggregate and reaggregate processes, which eventually produce a $32 \mathrm{x}$ 32 matrix. To obtain the relationship between industries and households, three variables, namely production sector, production factor and households, were chosen as endogenous variables as shown in Table 1.

In Table 1, production activities $\left(A_{11}\right)$ are aggregated into $22 \times 22$ matrix compared to $120 \times$ 120 matrix as classified by Malaysia IO Table 2005, published by the Department of Statistics Malaysia. The aggregation of production activities is accomplished by combining various related industries to form main sectors, such as agriculture, mining and quarrying, manufacturing, utility, construction, wholesale and retail trade, communication and other transports, finance, real estate, private services and government services. The restaurant sector is however not combined with any other industries as it is a single sector in itself as classified by MSIC 2000.

As discussed earlier, the tourism sector is not a single industry but rather a combination of several industries. Thus, for this present study, the tourism sector is considered as comprising of several sub-sectors which are shopping, transportation, accommodation, restaurance, entertainmance and recreational (Salleh et al. 2012). Data for the accommodation and entertainment sub-sectors for the SAM analysis can be obtained directly from the IO Table. However, data for restaurants, transportation, communication and shopping should be re-aggregated from the existing IO Table. The process of reaggregating the data is as follows:

1. Shopping sub-sector, the wholesale and retail trade sector is disaggregated into two with respective ratios; i) 0.653 for wholesale trade and motorized 
TABLE 1. Endogenous and exogenous accounts in SAM

\begin{tabular}{|c|c|c|c|c|c|}
\hline & \multicolumn{3}{|c|}{ Endogenous Account } & \multirow{2}{*}{$\begin{array}{c}\text { Exogenous account } \\
\text { Other account } \\
\text { additional revenue }\end{array}$} & \multirow[b]{2}{*}{ Total Income } \\
\hline & Production Activities & Production factors & $\begin{array}{c}\text { Institution } \\
\text { (Households and } \\
\text { firms) }\end{array}$ & & \\
\hline Production activity & $\begin{array}{l}\text { Intermediate Demand } \\
\qquad\left(\mathrm{A}_{11}\right)\end{array}$ & & $\begin{array}{l}\text { Final Demand } \\
\qquad\left(\mathrm{C}_{13}\right)\end{array}$ & $\begin{array}{c}\text { Export and } \\
\text { Investment }\left(\mathrm{ex}_{1}\right)\end{array}$ & $\begin{array}{l}\text { Total output and } \\
\text { demand }\left(\mathrm{Y}_{1}\right)\end{array}$ \\
\hline Production factor & $\begin{array}{c}\text { Value Added to } \\
\text { Production Sectors } \\
\left(\mathrm{V}_{21}\right)=\mathrm{T} 13 \text { Allocation } \\
\text { of value added to PF }\end{array}$ & $\mathrm{T} 130$ & $\mathrm{~T} 120$ & $\begin{array}{l}\text { Production Factor } \\
\text { income from other } \\
\text { accounts }\left(\mathrm{ev}_{2}\right) \\
\text { overseas }(\mathrm{X} 14)\end{array}$ & $\begin{array}{c}\text { Factorial } \\
\text { Income } \\
\text { distribution }\left(\mathrm{Y}_{2}\right)\end{array}$ \\
\hline $\begin{array}{c}\text { Institution } \\
\text { (Household and } \\
\text { firm) }\end{array}$ & & $\begin{array}{l}\text { Income allocation to } \\
\text { institutions }\left(\mathrm{Y}_{32}\right)\end{array}$ & $\begin{array}{l}\text { Institutional } \\
\text { transfer }\left(\mathrm{H}_{33}\right)\end{array}$ & $\begin{array}{l}\text { Foreign Transfer } \\
\qquad\left(e y_{3}\right)\end{array}$ & $\begin{array}{c}\text { Institutional } \\
\text { Income } \\
\text { distribution }\left(\mathrm{Y}_{3}\right)\end{array}$ \\
\hline $\begin{array}{l}\text { Other account } \\
\text { additional revenue }\end{array}$ & $\begin{array}{l}\text { Import, Indirect tax } \\
\qquad\left(\mathrm{L}_{1}\right)\end{array}$ & $\begin{array}{l}\text { Income allocation of } \\
\text { production factors to } \\
\text { foreign }\left(L_{2}\right)\end{array}$ & Saving $\left(L_{3}\right)$ & $\begin{array}{l}\text { Transfer and other } \\
\text { accounts }(T)\end{array}$ & $\begin{array}{l}\text { Other Income } \\
\qquad(\mathrm{YX})\end{array}$ \\
\hline Total expenditure & $\begin{array}{l}\text { Total Input and } \\
\text { Supply }\left(\mathrm{Y}_{1}{ }^{\prime}\right)\end{array}$ & $\begin{array}{l}\text { Production factors } \\
\text { expenditure }\left(\mathrm{Y}_{2}^{\prime}\right)\end{array}$ & $\begin{array}{c}\text { Institutions' } \\
\text { expenditure }\left(\mathrm{Y}_{3}{ }^{\prime}\right)\end{array}$ & $\begin{array}{c}\text { Other expenditures } \\
\left(\mathrm{Y}_{4}^{\prime}\right)\end{array}$ & \\
\hline
\end{tabular}

Source: Adapted from Defourny and Thorbecke (1984)

vehicle sector, and ii) 0.347 for retail trade sector. The disaggregation process is accomplished based on ratios given in Value Added Table for Services Sector at constant 2005 prices. Accordingly, 25 percent of the output of retail trade sector has been identified as part of the tourism sector (shopping) based on Malaysia Tourist Profile by Selected Market (publication in various years). Further, the output balance of retail trade sector is re-aggregated with the wholesale and motorized vehicle sector to form the wholesale and retail trade sector.

2. The transportation and communication sector, is disaggregated into two sectors, namely: a) transportation sector, and b) communication and other transports based on MSIC industrial code 2000. Further, 13 percent of the output of the transportation sector has been identified as part of the tourism sector (transportation) based on Malaysia Tourist Profile by Selected Market (various years). Similar to the wholesale and retail trade sector, the communication and transportation sector is created by re-aggregating the balance of transportation sector with the communication and other transport sector.

3. Restaurant, a total of 18 percent of the restaurant sector's output has been identified as part of the tourism sector (food and beverages) based on the Malaysia Tourist Profile by Selected Market (various years).

The production factor account is divided into two, namely labor account and capital $\left(V_{21}\right)$. The labor account is further split into two categories, namely, citizen and non-citizen. To obtain clearer and detailed study results, the citizen labor category is additionally divided into two groups, i.e. urban and rural. There are studies that split the household group in accordance an with the ethnic group in rural and urban areas, such as those by Saari et al. (2014) and Harun et al. (2012b). This study however disaggregated this group $\left(C_{13}\right)$ into three categories, namely citizen urban, citizen rural and non-citizen households. Since the majority of poor households are in rural areas, it is important that tourism impact on urban and rural households be gauged separately.

The common assumption used in IO Type 1 model is that the coefficient is assumed to be constant. Based on this assumption, the column of the inter-sectoral account will be divided from the respective sector's total columns. The coefficient is assumed to represent functions of production firms, which characterizes their respective sectors. By assuming that firms will respond to change in demand based on the production function parameter at a constant rate, a model can be specified as a simultaneous linear equation system. To obtain the coefficient, this model can be resolved by replacing final demand change to supply change for each sector (Miller $\&$ Blair 2009). As per the IO model, supply is assumed to always fulfil demand.

The IO account analysis can only determine the inter-industry relationship. However, the association between household income and expenses cannot be explained and similarly so with the relationships between government's income and expenditure, and between savings and investment. Thus, the identification of the relationship in the SAM account allows for the industry/ household relationship be determined in a similar way to the inter-industry relationship in the IO model. The determination of this relationship by the SAM model can be achieved when households, government and investment are considered as endogenous variables. 
By assuming household as endogenous in the SAM model, the following matrix is derived (Pyatt and Round, 1985), here is assume that endogenous accounts are production activities, production factors, and institutions, while other accounts being exogenous. Income distributions of endogenous accounts can be mathematically described as below:

$$
\begin{array}{ll}
\text { Total Output and Demand } & \mathrm{Y}_{1}=\mathrm{A}_{11}+\mathrm{C}_{13}+\mathrm{ex} 1 \\
\text { Factorial income } & \mathrm{Y}_{2}=\mathrm{V}_{21}+\mathrm{ev}_{2} \\
\text { Institutional Income } & \mathrm{Y}_{3}=\mathrm{Y}_{32}+\mathrm{T}_{33}+\mathrm{ey}_{3}
\end{array}
$$

Expenditure for endogenous accounts can be described as:

$$
\begin{array}{ll}
\text { Total input and Supply } & \mathrm{Y}_{1}{ }^{\prime}=\mathrm{A}_{11}+\mathrm{V}_{21}+\mathrm{L}_{1} \\
\begin{array}{l}
\text { Production factors' } \\
\text { expenditure }
\end{array} & \mathrm{Y}_{2}{ }^{\prime}= \\
\begin{array}{l}
\text { Institutions' Expenditure } \\
\mathrm{Y}_{32}+\mathrm{L}_{2}
\end{array} & \mathrm{Y}_{3}{ }^{\prime}=\mathrm{C}_{13}+\mathrm{H}_{33}+\mathrm{L}_{3}
\end{array}
$$

Matrix $\mathrm{T}$ as a transactional matrix between each endogenous account can be written as:

$$
\begin{gathered}
S=\left[\begin{array}{ccc}
A 11 & 0 & C 13 \\
V 21 & 0 & 0 \\
0 & Y 32 & H
\end{array}\right] \\
S=\left[\begin{array}{ccc}
A & 0 & C \\
V & 0 & 0 \\
0 & Y & H
\end{array}\right]
\end{gathered}
$$

Where: $\mathrm{S}=\mathrm{SAM}$ coefficient matrix, $A=$ technical coefficient matrix, $V=$ value-added coefficient matrix, $Y=$ value-added distribution coefficient matrix, $C=$ expenditure coefficient matrix, and $H=$ institutional and household distribution coefficient matrix. Not all intersections between balance sheets in the SAM framework have meaning and this corresponds to the true understanding of economics. The intersection between the balance sheets which has no meaning is indicated by the intersection with the symbol 0 . For example, the intersection between the balance of production factors and the factors of production has no meaning because in an economy there is never a production factor such as labor pays to other production factors such as capital or labor production factors. alone; and therefore, in the SAM frame it is given the symbol 0 . Likewise for other intersections which have the symbol 0 (Sutomo 2015).

In order to pursue the question of how the endogenous components of the model interact, we disaggregate $S$ into two additive matrices, one containing the blocks on the diagonal $(\mathrm{Q})$ and the other the offdiagonal blocks $(\mathrm{R})$, giving

$$
S=\mathrm{Q}+R
$$

where

$$
Q=\left[\begin{array}{ccc}
A & 0 & 0 \\
0 & 0 & 0 \\
0 & 0 & H
\end{array}\right] \text { and } R=\left[\begin{array}{ccc}
0 & 0 & C \\
V & 0 & 0 \\
0 & Y & 0
\end{array}\right]
$$

We can now rework the algebra of the previous section making use of this decomposition of the S matrix, the supply and demand balance equations as:

$$
\begin{gathered}
{\left[\begin{array}{l}
X \\
V \\
Y
\end{array}\right]=S\left[\begin{array}{l}
X \\
V \\
Y
\end{array}\right]+\left[\begin{array}{l}
e x \\
e v \\
e y
\end{array}\right]} \\
=Q\left[\begin{array}{l}
X \\
V \\
Y
\end{array}\right]+R\left[\begin{array}{l}
X \\
V \\
Y
\end{array}\right]+\left[\begin{array}{l}
e x \\
e v \\
e y
\end{array}\right] \\
=(I-Q)^{-1} R\left[\begin{array}{l}
X \\
V \\
Y
\end{array}\right]+(I-Q)^{-1}\left[\begin{array}{l}
e x \\
e v \\
e y
\end{array}\right]
\end{gathered}
$$

Where: $X=$ vector of sector supply, $V=$ vector of value-added by categories, $Y=$ vector of household, $e x=$ vector of exgenous commodity demand, $e v=$ vector of exogenous value-added, and $e y=$ vector of exogenous household incomes.

Where:

Then, define $T=(I-Q)^{-1} R$, hence, equation (9) becomes

$$
x=T x+(I-Q)^{-1} \text { ex }
$$

Further, equation (10) is multiplied with $T$, and is substituted with $T x$ in the same equation, thus obtaining

$$
x=T^{2} x+T(I-Q)^{-1} e x+(I-Q)^{-1} e x
$$

This equation is further expanded by multiplying equation (11) with $T$, and again is substituted with $T x$ in equation (9)

$$
\begin{gathered}
x=T^{3} x+T^{2}(I-Q)^{-1} e x+T(I-Q)^{-1} e x+(I-Q)^{-1} e x \\
=\left(I-T^{3}\right)^{-1}\left(I+T+T^{2}\right)(I-Q)^{-1} e x \\
=\mathrm{M}_{3} \mathrm{M}_{2} \mathrm{M}_{1} \text { ex }
\end{gathered}
$$

Hence, the following equations are obtained,

$$
\begin{gathered}
M_{1}=(I-Q)^{-1} \\
M_{2}=\left(I+T+T^{2}\right) \\
M_{3}=\left(I-T^{3}\right)^{-1}
\end{gathered}
$$

Stone (1986) proposed an additive variation of the decomposition developed by Pyatt and Round (1985), in which the decomposition becomes additive rather than multiplicative, according to this decomposition, SAM multiplier be established as follows: 
$(I-S)^{-1}=I+\left(M_{1}-I\right)+\left(M_{3}-I\right) M_{1}+\left(M_{2}-I\right) M_{3} M_{1}$

Where, $I$ is identity matrix and $(I-S)^{-1}$ is SAM inverse coefficient matrix

According to Stone (1986), there are three submultipliers as N1, N2, and N3, they are:

1. The direct effects or intragroup (own) effects that are similar to Pyatt and Round's multiplier is given as:

$$
N_{1}=M_{1}
$$

Direct effects indicate that, if there is an exogenous shock in a sector, the effects will be directly passed on to other production sectors.

2. Meanwhile, indirect effects indicate that the direct effects that happen to the sector in the economy indirectly will affect wage and income distributions to the production factors and households. The indirect effect or extragroup effects in non-diagonal matrix dimension is given as;

$$
N_{2}=M_{2} M_{3} M_{1}-M_{3} M_{1}
$$

3. Induced effects will occur when households, who received the income from indirect effect will spend their money to buy goods and services from the production sectors. Induced effect, or closed loop or intergroup effect is in the diagonal matrix dimension is given as:

$$
N_{3}=M_{3} M_{1}-M_{1}
$$

To obtain the total impact received by each sector, $N_{1}, N_{2}$, and $N_{3}$ are all multiplied with the income received from tourists. This will produce the direct, indirect and induced effects.

\section{EMPIRICAL FINDINGS}

Table 2 illustrates that if there is an external shock in the final demand of the tourism sector, for example, increasing in RM1 million of tourist expenditure, the entire inter-industry economic transactions will accrue an increase of RM9.93 million in output production. This will stimulate a production increase in the tourism sector by RM6.49 million with the highest contribution by the arts, entertainment and recreation sub-sectors with RM1.484 million. In addition, increments in other sectors showed the highest coming from the manufacturing sector with RM1.25 million, followed by RM0.49 million from the transportation and communication sectors, and RM0.39 million from the financial sector. On the other hand, the public service sector showed the least increase by RM0.046 million.
Indirectly, the increase in output production induced by the increased tourist spending will affect the wage of production factor and household income. An increase of RM1 million in tourist expenditures will indirectly affect rural labour wage by RM0.19 million, while RM1.14 million will accrue to urban labour, and the remaining RM0.038 million accrued to non-citizen labor. Due to the increase in income received by these workers, household income will also improve. The urban households' income will increase by RM1.9 million, while the rural households will receive RM0.35 million increment.

The induced effect occurs when the income received (as a result of tourist expenditure) by production factor and household, is spent on goods and services produced by the production sector. When the production factor and households receive their increased income of RM1 million accrued from tourist expenditure, the manufacturing sector will experience the highest output at RM1.08 million, followed by the financial sector at RM0.34 million and real estate at RM0.25 million. Conversely, the least induced effect is felt by the mining sector with an increase in output of only RM0.05 million, and similarly the public service sector by an increase of RM0.1 million. Additionally, the tourism sector will experience the induced effect of RM0.16 million due to the increase of RM1 million from tourist expenditure.

Table 3 shows the impact underwent by all economic sectors as a result of tourist expenditure in 2005, 2010, 2015 and the estimated expenditure for 2020 . The direct impact experienced by tourism sub-sector in 2005 was RM42,824 million (Table 3).

Where this sector includes several components, namely shopping, accommodation, food and beverages, transportation and art, entertainment and recreation. Based on the analysis results, on the existing components in tourism, the highest direct impact is for the accommodation and transportation components, each of which has a value of more than $27 \%$ in the tourism sub-sector. While the direct impact on the components of art, entertainment and recreation, the share was below $5 \%$, namely $3.83 \%$. This figure is expected to increase to RM107,926 million in 2020 with an annual growth rate of 6.35 percent. This increase is based on the estimated increase in Malaysia's GDP in 2020. In 2005, the tourism sub-sector that contributed the most income was the accommodation sector which recorded RM11,834 million. However, by 2020 the shopping sub-sector is expected to become the most prominent contributor at RM37,480 million.

In 2020 the estimated contribution from tourist spending to income of rural and urban workers are RM2,656 million and RM22,666 million, respectively. The corresponding annual growth rate is estimated at 6.31 percent for rural workers and 6.46 percent for urban workers. The increased income received by the workers will effect increases in household income accordingly. 
TABLE 2. Output Multiplier for each economic sector in Malaysia 2005

\begin{tabular}{|c|c|c|c|}
\hline Production Sector, Production Factor, Household and Institution & Direct effect & Indirect effect & Induced Effect \\
\hline Agriculture & 0.079 & & 0.148 \\
\hline Mining & 0.068 & & 0.050 \\
\hline Manufacturing & 1.253 & & 1.076 \\
\hline Utility & 0.305 & & 0.119 \\
\hline Construction & 0.095 & & 0.089 \\
\hline Wholesale and retail trade & 0.154 & & 0.169 \\
\hline Shopping* & 1.027 & & 0.016 \\
\hline Accommodation* & 1.186 & & 0.047 \\
\hline Restaurant & 0.063 & & 0.101 \\
\hline Food and beverage* & 1.381 & & 0.022 \\
\hline Transportation* & 1.411 & & 0.010 \\
\hline Other transportations & 0.487 & & 0.232 \\
\hline Finance & 0.395 & & 0.335 \\
\hline Real estate & 0.327 & & 0.247 \\
\hline Private services & 0.169 & & 0.130 \\
\hline Government services & 0.046 & & 0.101 \\
\hline Arts, entertainment and recreation* & 1.484 & & 0.068 \\
\hline Rural labor & & 0.193 & \\
\hline Urban labor & & 1.135 & \\
\hline Foreign labor & & 0.038 & \\
\hline Capital & & 3.718 & \\
\hline Rural household & & 0.348 & \\
\hline Urban household & & 1.902 & \\
\hline Foreign household & & 0.013 & \\
\hline Firms & & 2.755 & \\
\hline Total tourism sub-sector & 6.489 & & 0.164 \\
\hline Overall total & 9.931 & 10.102 & 2.964 \\
\hline
\end{tabular}

*tourism sub sector

Source: Analysis of study results

In 2005, rural and urban households received total income of RM2,526 million and RM13,820 million, respectively. In 2020, these figures are expected to increase to RM6,657 million with an annual growth rate of 6.67 percent for rural households, and RM36,701 million and 6.73 percent respectively for urban households.

Indirectly, the increase in output, the production due to an induced by increased in tourist spending. It will affect to the wage of production factor and household income. The increase on RM 1 million in tourist expenditure will indirectly affect rural labour wage at RM 0.19 million, while RM 1.14 million is received by urban labour. Meanwhile, the rest, RM 0.38 million is received by non citizen labour. Due to increase in income received by these workers, household income will also improve. The urban household income will also improve. The urban household imcome will increase by
RM 1.9 million, while rural household will be received RM 0.35 million.

The induced effect occurs when the income received by production factor and household. When the production factor and households received their income do to increase of RM 1 million in tourist expenditure, manufacturing sector will experience the highest output at RM 1.08 million, followed by financial sector at RM 0.34 million and real estate at RM 0.25 million. Meanwhile, the least induced effect is experienced by mining sector with increase in output at RM 0.05 miillion, and public service sector at RM 0.1 million. Additionally, the tourism sector will experience the induce effect of RM 0.16 million do to increase of RM 1 million from tourist expenditure.

Impact of tourism sector to all economic sectors as aresult of tourist expenditure in 2005, 2010, 2015 and the estimated for 2020, the direct impact experienced by 


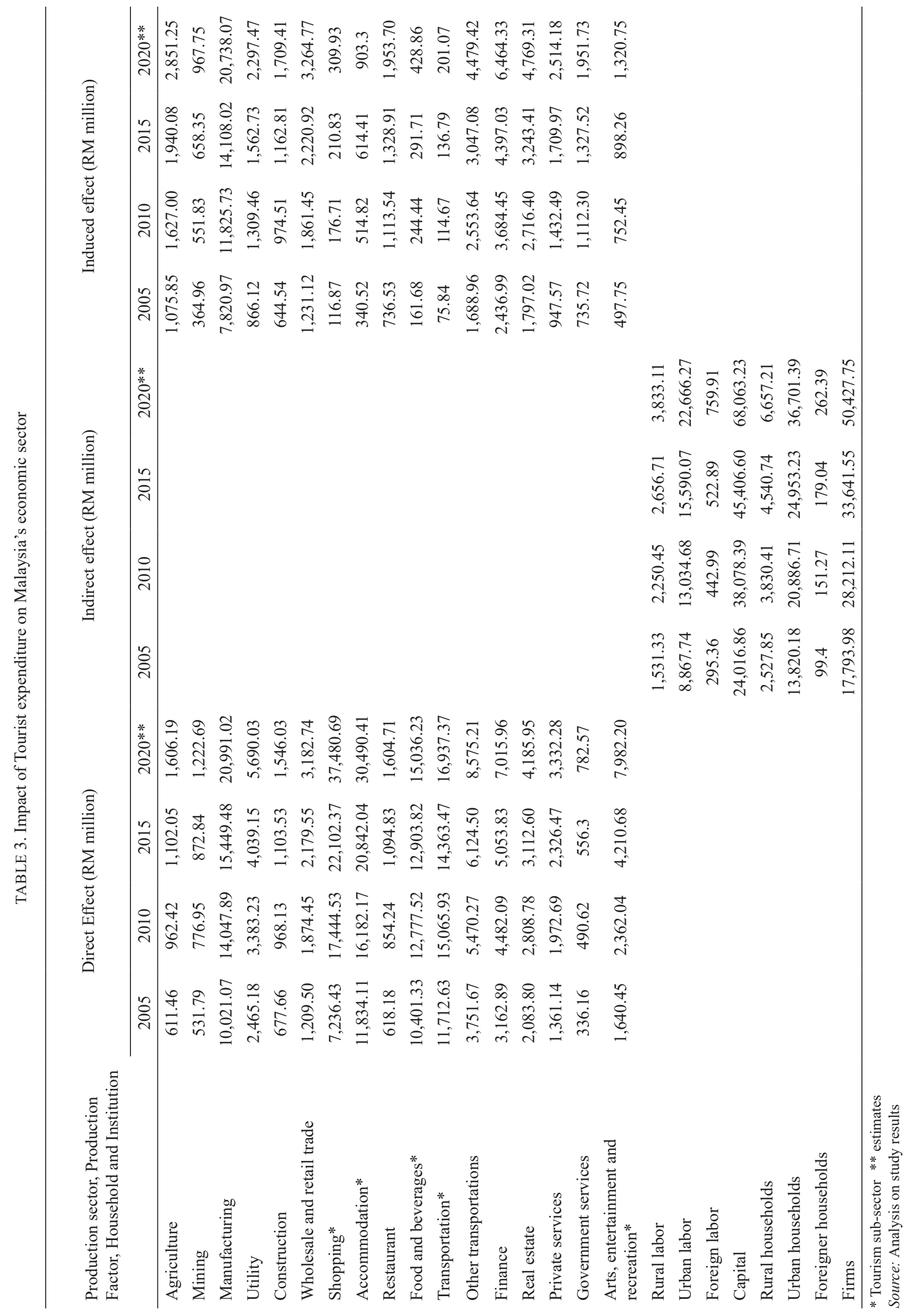


this sector at 2005 was RM 42,824 million. Meanwhile, for 2020, the tourism sector will be expected to increase to RM 107,926 million.

In 2005, the tourism sector that contributed the most income was the accommodation sector at RM 11,834 million. However, by 2020, the shopping sub sector is expected to become the most prominent contributor at RM 37,480 million. Meanwhile in 2020, due to spending by tourist, it estimated that the income received by rural and urban workers to be at RM 2,656 million and RM 22,666 million, respectively.

The increased household income indirectly an affect an increase in production activities because of the purchase of goods and services by households. With an annual growth rate of 6.72 percent, the indirect impact accrued from the tourism sector in 2020 is expected to be RM3,163 million compared to RM497.75 million in 2005 .

\section{CONCLUSIONS AND RECOMMENDATIONS}

When there is an external shock in demand, direct, indirect and induced income multipliers tend to indicate the complete impact on the economic cycle. This is evident in the study, where a shock on demand in the tourism sector was manifested and the direct income multiplier was shown to exert a direct impact on each production sector in the economic cycle. For example, spending by tourists will directly increase the income of the tourism sector and will additionally produce spillover effects on other sectors of production. The indirect effects of the tourist expenditure will subsequently have an impact on wages accrued by the production factor and households. Conversely, induced effect completes the cyclical impact on the economy when the production factor and households encouraged beneficiaries to spend their wages and income to purchase goods and services produced by the production sectors.

In this study, the tourism sector is considerd as the aggregate of several sub-sectors; namely shopping, accommodation, food and beverage, transportation, and arts, sports and recreation. Tourism multiplier illustrates several situations. First, tourist expenditure does not only increase income accruing to tourism sub-sectors but also produce spillover effects on other sectors in the economy. Second, the highest income multiplier for the tourism sector is from the arts, entertainment and recreation sub-sectors with the magnitude of 1.484; and third, the distribution of wages and income accrued to production factor (labor) and households because of changes in tourist expenditure show that rural labour and households receive less compared to those in the urban area.

In 2015 the total value of gross output generated by the arts, entertainment, and recreation sub-sectors was worth RM20.0 billion. From this, sports and recreational activities contributed to the highest quantum at RM17.2 billion or 86.2 percent (Department of Statistics Malaysia, 2016). Holding large-scale sports events are therefore one of several ways to empower this subsector. In consequence, long-term investments such as in infrastructure construction, improving services quality and transportation systems to host international-class sports events that attract tourists in large numbers need to be implemented. Large increases in government spending can be considerd appropriate since the development of the relevant sports facilities will have a long-term impact on not only the tourism sector but will also heighten the development and quality of national sports.

Overall, wages and income distribution to production factor and households from tourist expenditure shows a positive impact. Nevertheless, the income distribution is rather uneven which thus indicate that a sizeable income gap exists in labor and households between urban and rural areas. This, in turn, illustrates an inequitable distribution of benefits from the tourism sector. Progressive and continuous measures to overcome this inequality need to be implemented mainly to improve the income of rural populations. In this regard, developing more Community-Based Tourism in rural areas, is one of the measures that can be taken by the authorities. The economics of spillover effects of the tourism sector should elevate the income of the rural population. CBT reveals itself as a new opportunity for these farmers, through lodging, food, and leisure activities. In the countryside, tourism is now seen as a supplementary income for the families, keeping their authenticity, saving the cultural heritage, and improving their living conditions. In term of CBT development, it is promoting development-oriented policies that support productive activities, decent job creation, entrepreneurship, creativity, innovation, and encourage the formalization and growth of the business, including through financial help (Walkowski 2019).

By 2020, it is expected that the impact of tourist expenditure will increase substantially compared with those in previous years. Since the arts, entertainment and recreational sub-sectors produce the highest income multipliers, the authorities should consequently empower these sub-sectors by improving the quality and quantity of related activities to achieve the development targets by 2020 . But what happened is the opposite, this is due to the covid pandemic that has occurred around the world. This resulted in abnormal economic conditions, making it difficult to predict.

\section{REFERENCES}

Agostini, C. A., Brown, P. H. \& Roman, A. C. 2010. Poverty and inequality among ethnic groups in Chile. World Development 38(7): 1036-1046.

Akkemik, A. K. 2012. Assessing the importance of international tourism for the Turkish economy: A social 
accounting matrix analysis. Tourism Management 33(4): 790-801.

Alam, M. S. \& Paramati, S. R. 2016. The impact of tourism on income inequality in developing economies: Does Kuznets curve hypothesis exist? Annals of Tourism Research 61: 111-126.

Aliah, A. D. 2016. Role of the Tourism Sector in Economic Development in Indonesia: Social Accounting Matrix (SAM) Approach. Department of Resource and Environment Economics. Faculty of Economics and Management. IPB University. Bogor

Archer, B. \& Fletcher, J. 1996. The economic impact of tourism in the Seychelles. Annals of Tourism Research 23(1): 32-47.

Archer, B. H. 1995. Important of tourism for the economy of Bermuda. Annal of Tourism Research 22: 918-930.

Bank Negara Malaysia. 2012. Perkembangan Ekonomi Pada tahun 2012. http:/www.bnm.gov.my/files/ publication/ ar/bm/2012/cp01_002_rencana.pdf

Briassoulis, H. 1991. Methodological issues: Tourism input output analysis. Annals of Tourism Research 18: 485-495.

Croes, R. \& Rivera, M. 2015. Tourism potential to benefit the poor: a social accounting matrix model applied to Ecuador. Tourism Economics 23(1): 29-48.

Danial, M.J., Norman, W.C. \& Henry, M.S. 2004. Estimating income effects of a sports tourism event. Annals of Tourism Research 31(1): 180-199.

De Agostini, P., Lovo, S., Pecci, F., Perali, F. \& Baggio, M. 2005. Simulating the impact on the local economy of alternatif management scenarios for natural areas. Fondazione Eni Enrico Mattei. https://www.feem.it/ Feem/Pub/Publications/WPapers/default.htm

Defourny, J. \& Thorbecke, E. 1984. Structural path analysis and multiplier decomposition within a social accounting matrix framework. Economic Journal 94: 111-136.

Department of Statistics Malaysia. 2000. Malaysia Standard Industrial Classification (MSIC) 2000

Department of Statistics Malaysia. 2016. Economic Census 2016. Arts, Entertainment and Recreation Services. https://newss.statistics.gov.my/newss-portalx/ep/ epFreeDownloadContentSearch.seam?cid=150493

Department of Statistics Malaysia. 2018. Annual Gross Domestic Product 2010-2017. https://newss.statistics. gov.my/newssportalx/ep/epFreeDownload

Dwyer, L., Forsyth, P., Spurr,.R. \& Ho, T. 2004. The economic impact and benefits of tourism in Australia, a general equilibrium approach. Technical Report CRC Sustainable Tourism. Australia.

Dziauddin, M. F., Nayan, N. \& Ismail, K. 2016. Mengukur perubahan segregasi kaum di Malaysia menggunakan indeks entropi dan sistem maklumat geografi (GIS): Kajian kes negeri Perak bagi tempoh 1991-2000. GEOGRAFIA-Malaysia Journal of Society and Space 12(4): 12-25.

Eric, T. N. 2013. Tourism shocks, income distribution and poverty: a social accounting matrix approach for Kenya. In G. A. R. S. Aviation Student Research Workshop, 20$22^{\text {nd }}$ June 2013. Amsterdam University.

Fathurrahman, F., Kat, B. \& Soyta, U. 2017. Simulating Indonesian fuel subsidy reforma social accounting matrix analysis. Annals of Operations Research Journal 255(1): 591-615.
Fan, T. \& Oosterhaven, J. 2005. The impact of international tourism on the Chinese economy. Paper for the $15^{\text {th }}$ International input-output Conference, Beijing.

Fletcher, J. E. 1989. Input-output analysis and tourism impact studies. Annal of Tourism Research 16: 514-529.

Frechtling, D. C. \& Horvath, E. 1999. Estimating the multiplier effects of tourism expenditures on a local economy though a regional IO model. Journal of Travel Research 37: 324-332.

Hafiz, I. 2017. Tourism Malaysia unjur 31.8 juta pelancong. My Metro. January 11 https://www.hmetro.com.my/ node/196032

Harun, M., Mat, S. H. C. \& Jalil, A. Z. A. 2012a. Public expenditure expansion and inter-ethnic and reral-urban income disparity. Procedia Economics and Finance 1: 296-303.

Harun, M., Mat, S. H. C. \& Jalil, A. Z. A. 2012b. Impact of foreign direct investment on income distribution in Malaysia: Social accounting matrix framework. Global Review of Accounting and Finance 3(1): 32-42.

Hendry, E. W. \& Deany, B. 1997. The contribution of tourism to the economy of Ireland in 1990 and 1995. Tourism Management 18(8): 535-553.

Hughes, D. \& Shields, M. 2007. Revisiting tourism regional economic impact: accounting for secondary household employment. Review of Regional Studies 37(2): 186-206.

Johnson, R. C. \& Moore, E. 1993. Tourism Impact Estimation. Annals of Tourism Research 20: 279-288.

Kinyondo, A. \& Pelizzo. R. 2015. Tourism, development and inequality: The case of Tanzania. Poverty \& Public Policy 7(1): 64-79.

Kweka, J., Morrisey, O. \& Blake, A. 2003. The economic potential of tourism in Tanzania. Jurnal of International Development 15: 335-351.

Li, H., Chen, J. L., Li, G. \& Goh, C. 2016. Tourism and regional income inequality: Evidence from China. Annals of Tourism Research 58: 81-99.

Made, A. 1999. Linkages between tourism and agricultural in Bali-Indonesia: A social accounting matrix approach. A paperwork in International Seminar "Sustainable Tourism: The Balinese Perspective", Denpasar, Bali.

Mansury, Y. \& Hara, T. 2007. Impact of organic food agritourism on a small rural economy. A social accounting matrix approach. Tourism and Regional Science 37(3): 213-222.

Mazumder, N. H. M., Elsadig, M. A. \& Abul Quasem, A. 2009. Does tourism contribute significantly to the Malaysian economy? Multiplier analysis using IO technique. International Journal of Business and Managemant 4(7): 146-159.

Miller, R. E. \& Blair, P. D. 2009. Input-Output Analysis Foundations and Extensions. $2^{\text {nd }}$ ed. New York: Cambridge University Press.

MOTAC. 2015. Sejarah Kementerian Pelancongan dan Kebudayaan Malaysia. http://www.motac.gov.my/ profil/ sejarah

Norma, A. M.N., Salleh, N.H.M. \& Jaafar, A.H. 2014. Domestic tourist travelling patterns and their impact on the Malaysian economy. Journal of Hospitality and Tourism 12(1): 74-86.

Othman, R., Emaliana, R., Hasim, M. S. \& Salleh, N. H. M. 2011. Perbandingan corak lawatan dan kesan 
perbelanjaan pelancong kepada ekonomi Malaysia. International Journal of West Asian Studies 3(1): 29-48.

PEMANDU. 2011. Laporan Tahunan Pelan Transformasi Ekonomi 2011. http:/etp.pemandu.gov.my/ annualreport2011/12_National_Key_Economic_Areas(a)-Tourism.aspx

Polo, C. \& Valle, A. 2008. An assessment of the impact of tourism in the Balearic Islands. Tourism Economics 14(3): 615-630.

Pyatt, G. \& Round, J. I. 1985. Social Accounting Matrices: A Basic for Planning. Washington, DC: World Bank.

Saari, M. Y., Dietzenbacher, E. \& Los, B. 2014. Income Distibution across ethnic groups in Malaysia: Results from a new social accounting matrix. Asian Economic Journal 28(3): 25-278.

Saari, M. Y., Dietzenbacher, E. \& Los, B. 2015. Sources of income growth and inequality across ethnic groups in Malaysia 1970-2000. World Development 33: 311-328.

Saari,. M. Y., Rahman, M. A. A., Hassan, A. \& habibullah, M. S. 2016. Estimating the impact of minimum wage on poverty across ethnic groups in Malaysia. Economic Modelling 54: 490-502.

Saari, M. Y. \& Zakariah, A. R. 2006. Analisis Dan Aplikasi Input-Output. Kuala Lumpur: Dewan Bahasa dan Pustaka.

Salleh, M. N. H., Jaafar, A. H., Hasim, M. S. \& Othman, R. 2012. The pattern and the impact of Middle Eastern Tourist Spending on Malaysia Economy. Jurnal Ekonomi Malaysia 46(1): 53-63

Salleh, M. N. H., Jaafar, A. H. \& Othman, R. 2011. Impak perbelanjaan pelancong antarabangsa kepada ekonomi Malaysia. International Journal of Management Studies 18(1): 217-238.

Stone, R. 1985. The disaggregation of the household sector in the national accounts. In Social Accounting Matrices: A basic for planning edited by G. Pyatt \& J.J. Round, 145185. Washington, DC: World Bank.

Summary, R. 1987. Tourism contribution ti the economy of Kenya. Annals of Tourism Research 14: 531-540.

Surendra, B. P. 2000. Tourist's Consumption Pattern and its Economic Inpact in Nepal. New Delhi: Adroit Publishers.

Sutomo. S. 2015. Social Accounting Matrix: Keterkaitan Kinerja Ekonomi dengan Masalah-Masalah Sosial. Seri Materi Kuliah ke-5 Sistem Neraca Nasional. BPS. Jakarta

Taylor, J. E., Hardner, J. \& Stewart, M. 2006. Ecotourism and economic growth in the Galapagos: An island economy - wide analysis. Working Paper No 06-001. Giannini Foundation of Agricultural Economics.

Theobald, W. F. 2005. Global Tourism. $3^{\text {rd }}$ ed. London: Elsvier Butterworth Heinemann.

Thorbecke, E. 1988. The impact of stabilization and structural adjustment measures and reforms on agriculture and equity. In Policy Reform dan Equity: Extending the Benefits of Development edited by E. Berg. San Francisco: Institute for Contemporary Studies.
Tosun, C., Timothy, D. J. \& Ozturk, Y. 2003. Tourism growth, national development, and regional inequality in Turkey. Jurnal of Sustainable Tourism 11(2-3): 133-161.

Tourism Malaysia. 2018. Statistik ketibaan dan pendapatan pelancong. http://mytourismdata.tourism.gov.my/

Tourism Malaysia. (Various year). Malaysia Tourist Profile by Selected Markets.

UNWTO. (Various year). Tourism Highlight, Various Editions.

UNWTO. 2016. Tourism Highlight, 2016 Editions. https:// www.e-unwto.org/doi/book/10.18111/9789284418145.

van de Walle, D. \& Gunewardena, D. 2011. Sources of ethnic inequality in Vietnam. Jurnal of Development Economics 65(1): 117-207.

Wagner, J. E. 1997. Estimating the economic impacts of tourism. Annals of Tourism Research 24(3): 592-608.

Walkowshi, M. d. C., Pires, S. P. \& Tricárico, L. T. 2019. Community-based tourism initiatives and their contribution to sustainable local development. Journal of Sustainable Tourism and Entrepreneurship (JoSTE) 1(1): 55-67.

WTO. 1995. Concept, Definitions qnd Clasifications for Tourism Statistic. Technical Manual No.1 Madrid: World Tourism Organization.

Zakariah A. R. \& Bashir, M. B. 2004. Economic impacts of changing tourist profile in Malaysia. An inter-industrial analysis. Asean Journal of Hospitality and Tourism 3: 29-39.

Norma Azuli Mohd Nor

Faculty of Economics and Management

Universiti Kebangsaan Malaysia

43600 UKM Bangi, Selangor

MALAYSIA.

E-mail: normaazuli@gmail.com

Norlida Hanim Mohd Salleh*

Center of Sustainable and Inclusive Development

Faculty of Economics and Management

Universiti Kebangsaan Malaysia

43600 UKM Bangi, Selangor

MALAYSIA.

E-mail: ida@ukm.edu.my

A Faroby Falatehan

Department of Resource and Environment Economics

Faculty of Economics and Management

IPB University

Jln. Agatis Kampus IPB Darmaga, Bogor 16680

INDONESIA

E-mail: alfaroby@apps.ipb.ac.id

* Corresponding author 